\title{
Lapurdum
}

Euskal ikerketen aldizkaria | Revue d'études basques |

Revista de estudios vascos | Basque studies review

$21 \mid 2018$

Numéro XXI

\section{Morfema mugetako hots aldaketak Zaldibarko euskaran: Azterketa akustikoa}

\section{Ander Egurtzegi et Idoia San Martin}

\section{OpenEdition}

Journals

Édition électronique

URL : https://journals.openedition.org/lapurdum/3697

DOI : 10.4000/lapurdum.3697

ISSN : 1965-0655

Éditeur

IKER

\section{Référence électronique}

Ander Egurtzegi eta Idoia San Martin, «Morfema mugetako hots aldaketak Zaldibarko euskaran: Azterketa akustikoa», Lapurdum [Linean], 21 | 2018, Sarean emana----an 01 janvier 2018, kontsultatu 23 février 2022. URL: http://journals.openedition.org/lapurdum/3697 ; DOI: https://doi.org/10.4000/ lapurdum.3697

Creative Commons - Attribution - Pas d'Utilisation Commerciale - Pas de Modification 4.0 International - CC BY-NC-ND 4.0 


\title{
Morfema mugetako hots aldaketak Zaldibarko euskaran: Azterketa akustikoa
}

\author{
Ander Egurtzegi \\ CNRS, IKER UMR-5478 \\ ander.egurtzegi@iker. chrs. fr \\ Idoia San Martin \\ $U P V / E H U$ \\ isanmartin0140ikasle.ehu.eus
}

LABURPENA

Artikulu honen helburua Zaldibarko euskarako artikulu mugatuaren ahoskera zehaztea da, honen izaeran aldaketarik ematen ari den aztertuz. Honetarako, -e artikulua eta gainerako <e>en arteko ezberdintasun kualitatiborik dagoen ikertuko da, kategoria bakarra edo bi kategoria fonetiko ezberdin osatzen duten zehazteko. Aurreko bibliografian oinarrituta, gure aurreikuspena hurrengoa da: aldaketa historikoa osaturik egongo da eta igotako artikuluak eta gainontzeko/e/-ak ez dira ezberdinduko. Helburu honekin, bi adin taldetan banatutako zortzi pertsona grabatu ditugu. Guztira mugatzailearen erabilera eskatzen duten 18 hitz eta 18 esaldiren itzulpena egiteko eskatu genien, gazteleratik, Zaldibarren hitz egiten den euskarara. Gure emaitzen arabera, artikulu mugatuaren ahoskeran jazotako aldaketa historikoa geldirik da gaur egun, baina artikulua /a/ eta /e/-ren kokapenen arteko [ẹ] bezala egonkortu egin da. Modu berean, morfema mugako bokal talken ondorioz igotako/e/ [i] ikertu dugu. Kasu honetan, [i] honen ebakeraren eta /i/-ren beste adibideenaren artean gainjartze akustiko handia ikusi dugu: gure datuen arabera bokal talde biek kategoria fonetiko bakarra osatzen dute Zaldibarko euskaran. Azkenik, hiztun belaunaldi honetan morfema mugako [3]-ren ahoskabetze prozesuaren osatzearen aldeko behinbehineko ebidentzia aurkezten dugu.

Gako-hitzak: beheko bokalaren asimilazioa, hots aldaketa, fonetika akustikoa, artikulu mugatua, Zaldibarko euskara

\section{ABSTRACT}

The aim of this paper is to characterise the realisation of the definite determiner in the variety of Basque spoken in Zaldibar by identifying potential ongoing changes affecting it. To this end, we analyse whether there are any qualitative differences between the article -e and all other <e>s in the 


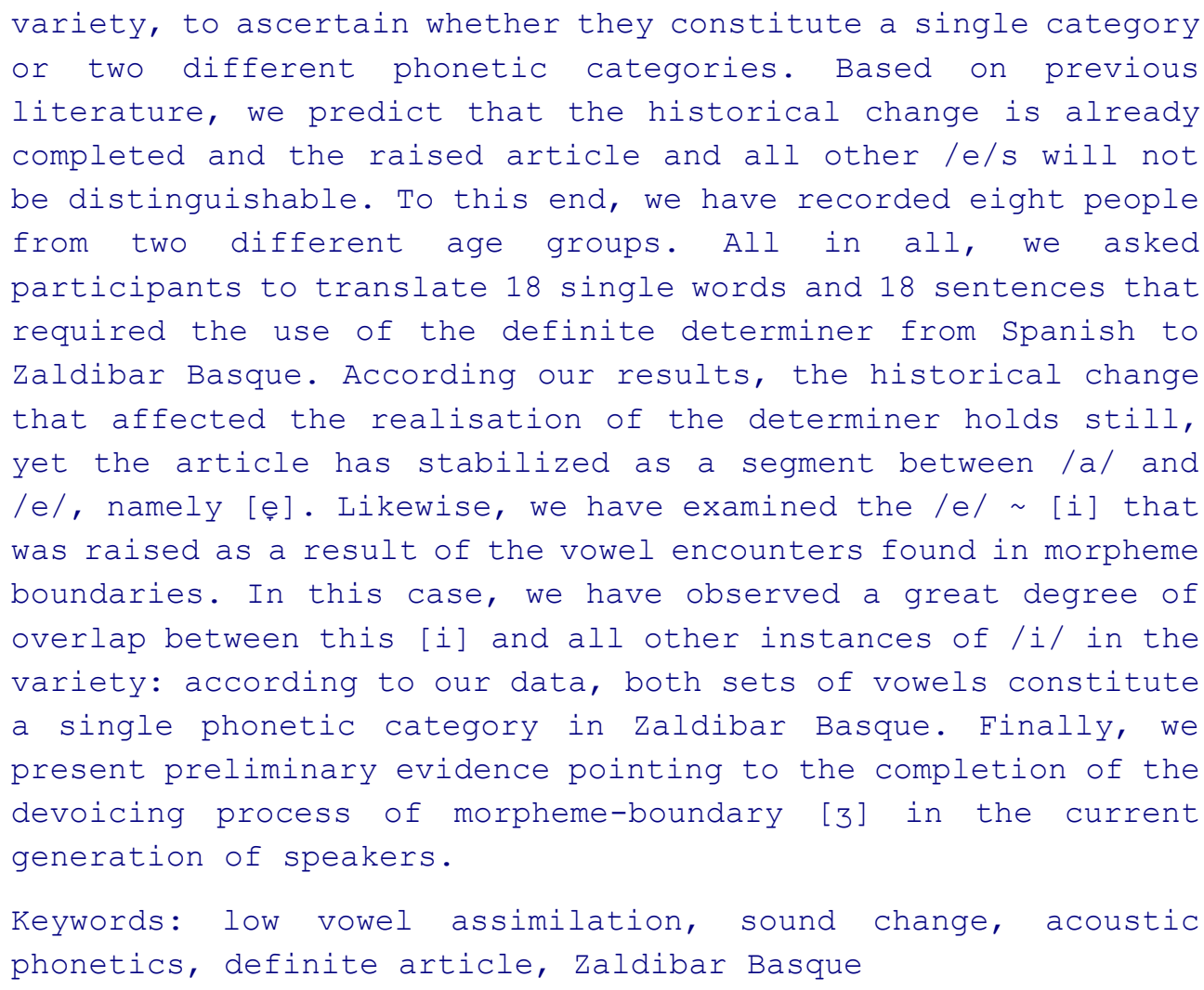

"Gainerakoaz den bezenbatean, batbederak daki heuskal herrian kuasi etxe batetik berzera ere minzatzeko maneran zer diferentia eta dibersitatea den" (Leizarraga, 1571:

\section{SARRERA}

Euskaraz idatzita agertu izan diren lehen testuetatik askotan nabarmendu izan den bezala, euskararen aldaera edo euskalkiak anitzak dira. Haien artean nolabaiteko batasuna dagoen arren, badira bata bestearengandik bereizten dituzten ezaugarriak ere. Desberdintasun hauek, hizkuntza bizirik dagoen heinean ezin direnak ekidin, denboran zehar emandako tokian toki jazotako aldaketa diakronikoen berri ematen digute. Lan honetan horrelako hots aldaketa zenbait landuko ditugu, guztiak bokalek bata bestearengan duten eraginaren ondorioz sortutakoak. Horretarako, Zaldibarko euskara izango dugu aztergai.

Euskal dialektologian euskalkien hainbat sailkapen egin izan dira, Oihenart (1656) eta Larramendiren (1745) oharretatik hasita, Bonaparteren mapetatik pasatuz (1863) eta Zuazoren proposamenetara arte (1998, 2003, 2008, 2014, 2019). Zuazok (2014) guztira bost euskalki - mendebalekoa, erdialdekoa, nafarra, nafar-lapurtarra eta zuberotarra 11 azpieuskalki eta 16 hizkera desberdindu zituen Euskal Herrian, nahiz eta, berriki, beste sailkapen batek (Aurrekoetxea et al. 2019) euskalkien kopurua hirura jaistea proposatu duen. 


\subsection{Mendebaleko euskara}

Azpimarratzekoa da sailkapen hauetan guztietan mendebaleko euskara beti gainerakoetatik bereizita agertu izana. Zuazoren esanetan (2017), honek mendebaleko euskalkiak duen nortasun eta izaera berezia erakusten du; bere ustetan, mendebaleko euskara luzaroan gainerakoetatik aldenduta egon izanak badu zer esanik (Zuazo 2014). Egun mendebaleko euskalkiak Bizkaiko, Gipuzkoako Deba ibarreko eta Arabako Aramaio eta Legutio udalerrietako eremu zabala hartzen du. Honek, alabaina, ez du esan nahi barne batasun handirik ez dagoenik; aitzitik, ezaugarri gehienak lurralde guztian zehar ematen dira eta ertzetik ertzera ezaugarriak alderatzen hasita, bidea etenik gabe egin daiteke (Zuazo 2003). Zuazok mendebaleko euskararen barruan bi azpieuskalki sartaldekoa eta sortaldekoa - eta zazpi hizkera ezberdintzen ditu (Zuazo 2003, 2008, 2014, 2017, 2019). Sartaldeko azpieuskalkian ipar-sartaldeko, hego-sartaldeko eta Nerbioi ibarreko hizkerak bereizten ditu. Sortaldekoan, ostera, Debagoieneko eta Deba ibarreko erdiguneko hizkerak. Bi azpieuskalkien artean Busturialdeko eta Otxandio aldeko hizkerak daude. Zaldibar Durangaldean (Bizkaian) kokatutako herria izanik, Mendebaleko euskaran kokatzen da, sortaldeko euskararen barnean hain zuzen ere, eta hortaz, bertako ezaugarriak ditu.

(Morfo-)fonologia alorrean (ikus Oñederra 2005 eta Manterola 2015), mendebaleko euskararen arau esanguratsuena - $a$ amaiera duten hitzei absolutibo singularreko $a$ gehitzean, hau da, $-a$ artikulua eranstean /-a + a/ > -ea bihurtzea da; adibidez, nesk $a+a$ $>$ neskea. Hala ere, jatorrizko aldaketa honen osteko bilakaera zenbaitek bokal sekuentzia hau eraldatu dute eta, hala, hizkeren arabera, -e (neské), -ia (neskia), -ie (neskie), -i (neskî) bezalakoak aurki ditzakegu egun (Zuazo 2017: 17). Arau hau hitz singularretan gertatzen da eta emankorra da egun; esate baterako, Zaldibarren, telebistie, kamarie, gasolinie, biomekanikie, robotikie, begetarianie, beganie, edota, mozzarelie esaten da inguruko beste zenbait herritan bezala, Mallabian kasu. Hala ere, lekuzko kasuak salbuespenak dira (eskolan, eskolatik, eskolako, eskolara, eskolaraino, eskolarako, eskolarantz, etab.). ${ }^{1}$

Bizkai sortaldeko hizkeren ezaugarri fonologiko espezifikoagoen artean, hiatoetan gertatzen diren hiru bilakaeren konbinazioa nabarmentzekoa da (Zuazo 2014, 2017). Alde batetik /e/ > /i/ /_V eta /o/ > /u/ /_V, esaterako, kale $+a>$ kalia/kalie eta bero $+a>$ berua/berue. Bestetik, /i/ eta /a, e, o/ artean - $x$ - [J] edo - $d x$ - [3] txistukariak gehitzen dira,

1 Aipatu behar da, nahiz eta lan honetan aztergai nagusia - $a$-ren gehiketaren ondoriozko aldaketak izan, beste bokal baten gehiketak ere aldaketa hauek eragin ditzakeela (semien 'semearen', neskiori 'neska hori', etab.). 
hala nola, mendi $+a>$ mendi $(d) x a / e$. Horrelakoetan, dagokigun Durangaldearen kasuan, mendidxe bezalako formak gailendu dira (Zuazo 2014: 218). Zaldibar sortaldean eta, zehatzago, Durangaldean izanik, arestian azaldutako bokal aldaketak gertatzen dira bertako hizkeran.

\subsection{Bokalen eraginaren ondoriozko hots-aldaketak}

Lan honetan ikertuko diren hots aldaketak artikulua eta antzerako morfemen gehiketak erroko azken bokalean eragindako bokal igoerak eta kontsonante epentesiak dira, alde batetik, eta, batez ere, artikuluaren beraren igoera asimilatiboa honen aurretik kokatutako bokal altu baten eraginez, haien artean kontsonante bat egon daitekeela (baina ez halabeharrez). Gamindek (1988, 1993, 2002, 2003) bi aldaketa talde hauek nabarmentzen ditu bizkaieraren bereizgarri bezala.

Bokal aldaketa hauek maiz izan dira landuak, bai gure artean eta baita kanpoan ere. Izan ere, bilakabide hauek nazioarteko fonologia teorikoan ezagunak dira eta askotan erabili izan dira hizkuntzalaritza historiko eta fonologia teorikoko eskuliburuetan (Trask 2015: 85, Kenstowicz 1994: 22-23, etab.). ${ }^{2}$

\section{Morfema mugako bokal topaketak}

Lehenengoari dagokionez, artikulu determinatzailea (hots, mugatzailea) erroari txertatzean, erroaren bukaerako bokalaren arabera aldaketa bat edo beste ematen da bokaletan (Gaminde 1988, 1993, 2002, 2003). Alde batetik, - $a$ determinatzailea - $a$-rekin amaitzen den hitz baten ostean erantsiz gero, $-e,-e a,-i a$, $-i e$, eta $-i$ emaitzak agertzen dira hizkeraren arabera (Gaminde 1988). Zaldibarren, /a/ + /a/ > /ie/ dugu, adibidez, alaba + $a>$ alabie (Gaminde 2003: 428). Modu berean, artikulua $-e$ baten ostean gehitzen bada, bizkaieraz -e, - ea, -ia, -ie, - $i$ amaierak suertatzen dira hizkeraren arabera (Gaminde 1988). Zaldibarren /e/ $+/ \mathrm{a} />/ \mathrm{ia} />/ \mathrm{ie} /$ aurkitzen dugu, esaterako seme $+-a>$ semie (Gaminde 2003: 428). Bestalde, artikulua erro amaierako - $i$ ondoren eranstean -i, -ie, -idxa, -ixa, idxe eta -ixe aldaerak ematen dira (Gaminde 1988), eta azken bi aldaerak agertzen zaizkigu Zaldibarren kasuan. Herri honetako nagusi gehienek igurzkari sabaikari ahostuna erabiltzen dute, gazteek, berriz, ahoskabea txertatzen dute (Gaminde 2002, 2003). Zaldibarren, beraz, artikuluaren gehiketak $\varnothing>\int / 3 / i_{-} V$ erregela eragiten du. Adibidez, idi $+-a>$ idixe / ididxe bezala ahoskatzen da (Gaminde 2003: 428). Honez gain, $-a$ artikulua $o$ bokalarekin amaitzen den hitz baten ondoren gehitzeak, - o, -oa, -ua,

2 Bokal aldaketa hauen bilduma zabal baterako, ikus Hualde eta Gaminde (1998). Analisi fonologiko ezberdinetarako, ikus de Rijk (1970); Hualde (1991, 1999) edota de Castro-Arrazola et al. (2015). 
$-u$, eta - $u$ e aldaerak eragiten ditu (Gaminde 1988). Zaldibarren /o/ + /a/ > /ua/ > /ue/, hala nola, asto $+-a>$ astue (Gaminde 2003: 428). Azkenik, $-a$ mugatzailea $-u$ ostean txertatzean $-u$, - $u$, eta $-u a$ emaitzak suertatzen dira (Gaminde 1988). Zaldibarren, $/ \mathrm{u} /+$ /a/ > /ue/, esaterako katu $+-a>$ katue (Gaminde 2003: 428).

Mendebaldeko artikulu mugatzaile singularreko ${ }^{3} / \mathrm{a} / \mathrm{+} / \mathrm{a} / \mathrm{>} / \mathrm{ea} /$ lehendabizi gertatu zen igoera da, beste aldaketekiko ezberdintasun handiarekin. Honakoa Erdi Aroko toponimian eta XVI. mendeko lehen testuetatik agertzen zaigu (e.g. Fray Juan de Zumarragaren 1537ko gutuna edota 1596ko Refranes y sentencias, ikus Hualde \& Gaminde 1998: 44). Horren osteko prozesuak zehaztasun geografiko handiagoarekin koka daitezke. Oraingoan dagokigun Durangaldean, XVIII. mendearen erdian ditugu /e/ $+/ \mathrm{a} />/ \mathrm{ia} /$ eta $/ \mathrm{a} / \mathrm{l} / \mathrm{a} / \mathrm{>} / \mathrm{ia} /$-ren lehen adibideak, eta XIX. mendearen hasierarako gainontzeko bokal topaketetako igoerak ere agertzen dira (Zuloaga 2015, 2019; Azaola 2019). ${ }^{4}$

\section{Beheko bokalaren asimilazioa}

Aipatutako bigarren ezaugarria artikulu honen ikergai nagusia izango da: /a/ sistematikoki /e/ bihurtzea aurretik (hautazko kontsonanteren bat eta) /i/ edo /u/ dituenean (Gaminde 1988: 15-16; Hualde 1991; Hualde \& Gaminde 1998), hau da, /a/ > /e/ / $\{\mathrm{i}, \mathrm{u}\}(\mathrm{C})_{\text {_. }}$. Erregela honi izen asko eman zaizkio; hauen artean rui erregela (de Rijk 1970) edota bokalen harmonia (Gaminde 1988). Lan honetan beheko bokalaren asimilazioa deituko dugu (aurretiaz ere erabilia izan dena, e.g. Hualde 2003 edota Zuloaga 2017). Beheko bokalaren asimilazioa hitz amaieran gertatzen da batez ere, morfema flexiboei eraginez (adibidez mutila > mutile eta txakurra > txakurre), baina hitz barruan (ikatza > iketza eta bularra > bulerra) edota hitzaren mugak gaindituz ere gerta daiteke, bat zenbatzailearen kasuan bezala (mutil bat > mutil bet eta txakur bat > txakur bet). Nolanahi ere, azken testuinguru hau ez da herri guztietan aurkitzen: lan honetan ikergai den Zaldibarren, adibidez, laguna > lagune baina lagun bat esaten da, bokal igoerarik gabe (Gaminde 2002: 8, 2003: 428). Asimilazio prozesu honen emaitza den bokala /e/-rekin neutralizatzen da euskalki gehienetan (Hualde 2003: 46). Hala ere, Azpeitia eta Azkoitiaren inguruko landa eremuan $[\varepsilon]$ edo [æ]-ren antzerako bokal bat deskribatu izan

\footnotetext{
3 Ez ordea pluralekoa, zein - $a k$ bezala soildu den orokorrean eta leku zenbaitetan (Oñatin kasu) gaur egun aldatu gabeko sekuentzia bezala agertzen den (neskaak, etab.). /a/ + /a/ > /ea/-ren osteko beste aldaketa guztiak berdin gertatu dira forma singular zein pluraletan (Hualde \& Gaminde 1998: 46).

4 Hala ere, Arzadunen 1731ko dotrinan badaude kasu jakin batzuetako adibideak (e.g. aditzak eta genitiboak); ikusi Zuloaga (2019: 249-251) adibide zehatzetarako.
} 
da, Yrizarrek (1991: I, 366) $\ddot{a}$ bezala markatzen duena, hizkera horietako /e/-ren ezberdina eta horrekin fusionatzen ez dena (ikusi Hualde \& Gaminde 1998: 44).

Historikoki, beheko bokalaren asimilazioa euskara zaharretik dokumentatuta dago, Zuloagak (2019: 663) XVII. mendearen hasieran kokatzen duela prozesu honen hastapena, lehenago ez bada. Beheko bokalaren asimilazioa hots aldaketa poligenetikoa da, eta XVIII eta XIX. mendeetan zehar hizkera ezberdinetako testuetan aurki daiteke Hego Euskal Herria gehienean zehar. Dagokigun Bizkaiko erdi-ekialdera beranduago heldu bide zen, XIX. mendearen bigarren erditik aurrera (Zuloaga 2019: 663). Beheko bokalaren asimilazioa bokal topaketa guztiak baino beranduago heldu zen Durangora, XX. mende aldera seguruenik (XIX. mende amaieran edo XX. mendearen hasieran; cf. Zuloaga 2019; Azaola 2019). Hala ere, Bizkai erdi-ekialdeko landa-eremu eta herriak hiri bilduetatik (hau da, Gernika edo Durango) bereizi behar dira: badirudi berrikuntza hauek landa eremuetatik zabaldu zirela hiri bilduetara eremu honetan (Zuloaga 2019).

Azkenik, Gaminderen arabera (2003: 428), azkar hitz egitearen ondorioz, “' $u$ ' eta 'i'ren ostean 'e' gal daiteke berbeta arinean batez ere kontsonante baten aurrean: astuk, katuk, semik, olakotxik". Aipatu behar da gure datuek ez dutela artikuluaren galeraren ebidentziarik erakusten testuinguru horietan, eta ikerketa honen bigarren autoreari (zaldibartarra dena), ez zaiola ezaguna egiten. Hala eta guztiz ere, kontuan izan behar dugu Gaminderen eta gure ikerketaren artean ia 20 urte pasa direla.

Beraz, 1. adibideko erregelak ditugu Zaldibarren. Kontuan izan behar da hurrenkera eta garaiak Durangoko datuetatik ateratakoak direla (i-vi) erregelen kasuan, Zaldibarreko datu zehatzik ez baitaukagu, eta dinamika ezberdinak egon daitezkeela Durangotik Zaldibarrera nahiz eta geografikoki hurbil egon (gogoan izan bilakabide zenbait beranduago heldu zirela Durango bezalako hirietara).

\section{(1) Morfema-mugetako erregelen hurrenkera Durangon (} Zaldibarren)

$\begin{array}{lllllll} & \text { Erregela } & & \text { Garaia } & \text { (neska) } & \text { (bero) } & \text { (mendi) } \\ \text { i- } & \mathrm{a}>\mathrm{e} & \text { /_V } & \text { Erdi Aroa } & \text { neskea } & - & - \\ \text { ii- } & \mathrm{e}>\mathrm{i} & \text { /_V } & \text { XVIII } & \text { neskia } & - & - \\ \text { iii- } & \varnothing>\mathrm{j} & \text { /i_V } & \text { XVIII } & - & - & \text { mendija } \\ \text { iv- } & \mathrm{o}>\mathrm{u} & \text { /_V } & \text { XIX } & - & \text { berua } & -\end{array}$

5 Diego Lorenzo Urkizuren obran (e.g. 1737ko kopla batzuetan eta 1740ko zortzikoetan) agertzen dira lehenengoz (ii) eta (iii) erregelen adibideak Durangon (Zuloaga 2015, 2019: 249-251). Hala ere, (iii)k hasia behar zuen (ii) osatu aurretik, (iii)k ez baitzituen (ii)k igotako bokalak eragin. Honakoa da ordena arruntena bi erregelak gertatu diren hizkeretan (ikus. Zuloaga 2019: 486, nahiz eta beste eremu bati buruz izan). 
Ander Egurtzegi, Idoia San Martin

$\begin{array}{lllllll}\text { v- } & \mathrm{a}>\mathrm{e} & /\{\mathrm{i}, \mathrm{u}\}(\mathrm{C})_{-} & \mathrm{XIX} & \text { neskie } & \text { berue } & \text { mendije } \\ \text { vi- } & \mathrm{j}>3 & & \mathrm{XIX}-\mathrm{XX} & - & - & \text { mendidxe } \\ \text { vii- } & 3>\int & & 1970-80 & - & - & \text { mendixe } \\ \text { viii- } & \mathrm{e}>\varnothing & /\{\mathrm{i}, \mathrm{u}\}_{-} \mathrm{C} & 1990(?) & \text { neskik } & \text { beruk } & -\end{array}$

\subsection{Lanaren helburua}

Behin Zaldibarren hitz egiten den euskararen ezaugarri fonologikoak zehaztuta, hau da, hizkera honetan hitzei mugatzailea gehitzearen ondorioz bokaletan gertatzen diren egokitzapenak aztertuta, Zaldibarko hizkeran nagusi den $-e$ artikuluaren ezaugarri akustikoei erreparatuko diegu. ${ }^{6}$ Ikerketa honek helburu nagusi bat du eta zenbait bigarren mailako helburu gehiago: alde batetik, $-e$ artikuluaren eta gainerako /e/ guztien artean ezberdintasun akustikorik dagoen egiaztatu nahi dugu, eta, horrela balitz, belaunaldi batetik bestera $-e$ determinatzailearen ahoskeran ezberdintasunik antzematen den ikusi nahi dugu. Horrez gain, gure korpusean $-e$ aurretik gertatutako $(/ \mathrm{a} />) / \mathrm{e} />/ \mathrm{i} /$ igoera erakusten duten kasuak daudenez, /i/ honen ezaugarri akustikoei ere erreparatuko diegu ikuspegi zabalago bat eskaintzeko asmoz. ${ }^{7} \mathrm{Bi}$ helburu hauek osatzeko bokal guztiak analizatuko ditugula baliatuta, artikulu honetan Zaldibarko bokalen espektro akustikoa erakutsiko dugu. Azkenik, gure korpusaren parte direla baliatuta berriro ere, igurzkari aurresabaikariak labur analizatuko ditugu hauen ahoskabetzea osatu den edo Zaldibarko euskaran oraindik ebakera ahostunak dauden ikusteko. Helburu gehienak betetzeko nolabaiteko dimentsio diakronikoa behar denez, adinaren arabera banatutako bi partehartzaile talde sortu genituen grabazioak egiterakoan.

Honakoa bezalako alegiazko-denbora ikerketetan (Bailey et al. 1991; Cuckor-Avila \& Bailey 2013; ikus. Weinreich et al. 1968) hiztun komunitate jakin baten gazte eta helduen hizkerak konparatzen dira. Konparazio honen atzean dagoen ustea hurrengoa da: bi belaunaldien artean nabari daitezkeen ezberdintasunek aldaketa historiko bat erakusten dutela, gutxi gora-behera belaunaldi gazteena eta belaunaldi zaharrenaren arteko batez besteko adin desberdintasunaren baliokidea den epe batean garatu direnak (Labov 1994).

6 Lan honetan $-e$ artikulu determinatzailea /E/ bezala irudikatuko dugu; bere izaera ikergai dugunez, aurretiaz bere ahoskera /a/-ren eta /e/-ren ahoskerengandik ezberdintzeko. Aldiz, beste $\langle a\rangle$ eta $\langle\mathrm{e}\rangle$ guztiak /a/ eta /e/ bezala agertuko dira lan honetan.

7 Bokal (i.e., - $e$ artikulua) aurretik igotako <i> guztiak /I/ bezala irudikatuko ditugu, beste $<\mathrm{i}>$-ak (etimologikoki /i/ direnak), ostera, /i/ bezala. 
Zaldibarko zortzi hiztuni pasatu genien esperimentua. Haien egitekoa artikulu mugatuaren erabilera eskatzen zuten hitz eta esaldiak gazteleratik Zaldibarren hitz egiten den euskarara itzultzea zen.

\section{METODOLOGIA}

\subsection{Parte-hartzaileak}

Guztira Zaldibarko 8 pertsonak hartu zuten parte esperimentu honetan. Hauek bi taldetan bereizi ditugu, adinaren arabera: gazteen taldea (batez besteko adina, $\mu=23,5$ urte, $\mathrm{SD}=$ 2.3805; adin tartea $=22-27$ urte, taldekideak: 1-4 hiztunak), eta nagusien taldea (batez besteko adina, $\mu=57,75$ urte, $\mathrm{SD}=7.5884$; adin tartea $=47-64$ urte, taldekideak: 5-8 hiztunak). Era berean, talde bakoitza bi emakumek eta bi gizonek osatzen dute, lau emakume eta lau gizon guztira.

Parte-hartzaile guztiak Zaldibarren jaio eta bizitakoak dira eta, ondorioz, herriko hizkera zein gaztelera menperatzen dituzte. Gazteei dagokienez, guztiek burutu zuten lehen hezkuntza Zaldibarko eskolan, bigarren hezkuntza Iurretako (Bizkaia) eskolan eta unibertsitate ikasketak Bilbo (Bizkaia) edo Arrasaten (Gipuzkoa). Guztiak euskara batuan ikasitakoak dira aurretik aipatutako hiru ikasketa epeetan zehar. Aitzitik, nagusien taldeko inor ez da euskaraz eskolatua izan, haien euskararen erabilera familia eta lagunartera mugatzen da.

\subsection{Materialak}

Esperimentu honetako materiala gaztelerazko 18 hitz eta SOV ordena jarraitzen duten 18 esaldi sinplek osatzen dute hurrenez hurren (ikusi eranskina). Item hauek bi zerrenda ezberdinetan banatu genituen parte-hartzaileek hitz eta esaldi berdinak baina ordena desberdinean itzul zitzaten Zaldibarko euskarara. Horrela, talde bakoitzeko emakume eta gizon batek A hurrenkera izan zuen, besteak, ordea, B hurrenkera. Hurrenkera jakin batek ahoskatzean identifikatu gabeko eraginen bat izango balu, hurrenkera ezberdinak erabiltzeak eragin honen garrantzia gutxitzeko hartu genuen erabaki hau. Edonola ere, hitzen beraien eragina kontuan hartzeko "item" ausazko aldagai bezala gehitu dugu gure modelo estatistikoan (ikusi beherago).

Hitz eta esaldi guztiek artikulu determinatzailearen erabilera bilatzen dute. Zaldibarko euskarako artikulu determinatzailearen itzulpenetan, guztira, - $a$-ren asimilazioa eragiten duten sei patroi ezberdin identifika daitezke, hitz isolatu zein esaldietan txertatutako hitzetan. Lehenik eta behin, beheko bokalaren asimilazio ez-lokalaren bi kasu aurki daitezke, hau da, /a/ > /e/ igoeraren eragile den bokalaren (/i/ edo /u/) eta eragindako /a/- 
ren artean kontsonante bat edo gehiago daudenean (i.e., la llave $=$ giltza $>$ giltze eta la nieve $=$ elurra $>$ edurre $)$. Gainerako $4 \mathrm{kasuak} / \mathrm{a} / \mathrm{l} / \mathrm{e} / \mathrm{/} / \mathrm{i} / \mathrm{eta} / \mathrm{u} / \mathrm{bokalez}$ bukatzen diren hitzei - $a$ artikulu determinatzailea eranstean sortutako bokal aldaketei dagozkie: /a/ $+/ a /$ $>/ \mathrm{ie} /($ la tripa $=$ tripa $>$ tripie $), / \mathrm{e} /+/ \mathrm{a} />/ \mathrm{ie} /($ la ballena $=$ balea $>$ balie $), / \mathrm{i} /+/ \mathrm{a} />/ \mathrm{i} \mathrm{je} /$ $($ el sol $=$ eguzkia $>$ eguzkixe $)$ eta $/ \mathrm{u} /+/ \mathrm{a} />/ \mathrm{ue} /($ la mano $=$ eskua $>$ eskue $)$ Guztira, korpusean kasu mota bakoitzeko 6 hitz daude, 3 isolaturik eta 3 esaldietan tartekatuta, alegia.

\subsection{Prozedura}

Esperimentua banan-banan pasatu genien parte hartzaileei Zaldibarren bertan, haietako bakoitzaren etxean; zarata nabarmenik gabeko gela batean, eta ahal izan den neurrian kanpoko hotsak ekidinez. Parte-hartzaileak mahai baten aurrean eserita zeuden. Aurrealdean 18 hitz eta atzealdean 18 esaldi dituen paper bat eman genien eta hitzok/esaldiok gazteleratik familia eta lagunekin komunikatzeko erabiltzen duten Zaldibarko euskarara itzultzeko eskatu genien. Horretarako, hitz eta esaldi bakoitza, lehenengo, haien bururako irakurtzeko eta, jarraian, ozen itzultzeko eskatu genien. Guztira, esperimentu bakoitzak 5 minutu inguru iraun zuen.

\subsection{Datuen tratamendua}

Grabazioak Huawei Mate 9 telefonoa erabiliz eta Voice Recorder PRO aplikazioaren bidez egin ziren, $44.1 \mathrm{kHz}-\mathrm{ko}$ lagin hautaketa maiztasunarekin. Grabazio guztiak burutu ostean, audioak Audacity (Audacity Team 2019) programaren bidez moztu eta WebMAUS (Munich Automatic Segmentation System, ikusi Kisler et al. 2017) online aplikazioaren bidez automatikoki segmentatu ditugu, artikulu honen lehen autoreak hegoaldeko euskal hizkerentzako egokitutako "Basque (ES)" funtzioa erabiliz. Ondoren, anotazio guztiak TextGrid formatuan esportatu eta Praat-en bidez (Boersma \& Weenink 2019) eskuz zuzendu ditugu, analisi akustikoaren egokitasuna bermatzeko. Bokalen analisi akustikoa Praat-en egin da, ikerketa honetarako bereziki moldaturiko funtzioak erabilita.

Guztira 1805 token bokaliko analizatu ditugu, 222 eta 236 bokal artean hiztun bakoitzeko $(\mu=225.625, \mathrm{SD}=4.438)$. Formakinen estimazioak Praat-en bidez kalkulatu ditugu, Burg LPC metodoa jarraituz. Formakinen estimazioa emakume vs. gizonentzako optimizatu dugu gehienezko formakinen parametroa doituz. Emakumeen kasuan, bostgarren formakinaren sabaia $5500 \mathrm{~Hz}$-tan ezarri dugu; gizonena, ordea, $5000 \mathrm{~Hz}$-tan ezarri dugu. F1, F2, eta F3ren balioa neurtu dugu bokal bakoitzaren erdi-puntuan, bokal bakoitzaren iraupenarekin batera (ms.-tan). Behin neurketa guztiak bilduta, Praat-en bidez lortutako datuak zerrendatu ditugu informazioa esportatu ahal izateko. Analisi eta bisualizazio prozesu guztia $R$ (R Core Team 2019) software-aren bidez aurrera eraman 
dugu. Hasteko, hiztunen arteko bariazioa ekiditeko, neurketak Lobanov normalizazioaren bidez moldatu ditugu (i.e. $z$-balioen transformazioa). Honen ondorioz lortutako $z$-balioak berriro Hz-tara pasa ditugu, desbideratze estandarra (SD) eta 8 hiztunen batezbesteko handia (hau da, hiztun guztien batezbestekoen batezbestekoa) erabiliz. Formakinen balio normaldu hauek z-balioak baino ulertzeko errazagoak dira, eta hauen izaera normalizatua mantentzen dute. Normaldutako F1 eta F2 balioak kategoria bakoitzaren baitan (/i, I, e, E, a, o, u/) konbinatu eta bokal bakoitzeko z-balioak kalkulatu ditugu. Grafikoak argiago erakusteko helburuarekin, outlier edo muturreko datuak, bokal bakoitzaren behaketen testuinguruan 3 baino balio absolutu altuagoko F1 edo F2-ren z-balioak dituzten behaketak, alegia, bisualizazioetatik baztertu ditugu, baina estatistikan datu guztiak erabili dira. Metodologia hau aurreko lanetan erabilitakoan oinarrituta dago (e.g. Egurtzegi \& Carignan 2020), eta honen azalpen sakonagoa aurkitu daiteke bertan.

Igurzkari aurresabaikariari dagokionez, 50 token analizatu ditugu, 4 eta 8 segmentu artean hiztun bakoitzeko $(\mu=6.25, \mathrm{SD}=1.282)$. Hasiera batean igurzkari aurresabaikariaren ahoskabetzea begiratzeko ideiarik ez genuenez, nahi baino token gutxiago lortu genituen grabaketan. Edonola ere, grabatutako segmentu gutxi horien analisia lehen ikerketa esploratzaile bezala informatiboa izango delakoan gaude. Segmentu bakoitzeko, autokorrelazio (AC) koefizienteak neurtu ditugu Emu programaren bidez (ikus Harrington 2010 bertsio klasikorako eta Winkelmann 2017 emuR $R$ paketearentzako). ESPS metodoa erabiliz, 10 ms.-ro neurketa bat egin dugu, $7.5 \mathrm{~ms}$.-ko zabalerako leihoak eta $60 \mathrm{~Hz}$-tik $400 \mathrm{~Hz}$-rainoko doinu tartea zehazturik. Honela, guztira 520 AC neurketa lortu ditugu, bakoitza 0 eta 1 arteko ahostuntasun koefiziente batekin: 0-k korrelaziorik ez dela esan nahi du (eta beraz, segmentua ahoskabea dela denbora puntu horretan), eta 1-ek korrelazioa osoa dela (eta ondorioz segmentua ahostuna dela momentu jakin horretan). Gero, neurketa horien mediana kalkulatu dugu segmentu bakoitzeko balio bakar bat lortzeko. Metodologia hau ere aurreko lanetan erabili izan dugu; azalpen sakonago baterako, ikus Blevins, Egurtzegi eta Ullrich (2020).

\section{EMAITZAK}

\subsection{Bokalen eremu akustikoa}

1. Irudiak Zaldibarko euskararen bokalen F1-F2 eremu akustikoa erakusten du eta bertako euskararen 5 bokalez gain (/i, e, a, o, u/), ikerketa honetan galdegai diren [E] eta [I] segmentu posibleak biltzen ditu. Bokalen eremu akustikoaren karakterizaziorako, hiztun guztien normaldutako F1 eta F2 balioak konbinatu ditugu eta muturreko balioak baztertu, bokal bakoitza puntu batek errepresentatzen duela eta elipseek kategoria bakoitzeko bariazioaren $\% 50$ biltzen dutela. Bokalen sinboloek kategoria bakoitzeko F1/F2 batezbestekoa markatzen dute, eta marra beltzek bost bokal kontrastiboen batezbestekoak konektatzen dituzte. Honekin batera, 1. Taulan analizatutako bokal bakoitzarentzako 
estatistika laburkina ematen da. Honetan, korpusean agertzen den bokal bakoitzaren kopurua $(\mathrm{N})$, eta F1 eta F2-ren batez-bestekoa ( $\mu$ ), desbiderapen estandarra (SD) eta errore estandarra (SE) ematen da. Hiztunen arteko ezberdintasunak egiaztatu ahal izateko, 2. Irudian parte-hartzaile bakoitzaren F1-F2 eremu akustikoa bereizirik erakusten da.

Irudia 1 Bokalen eremu akustikoaren irudikapena

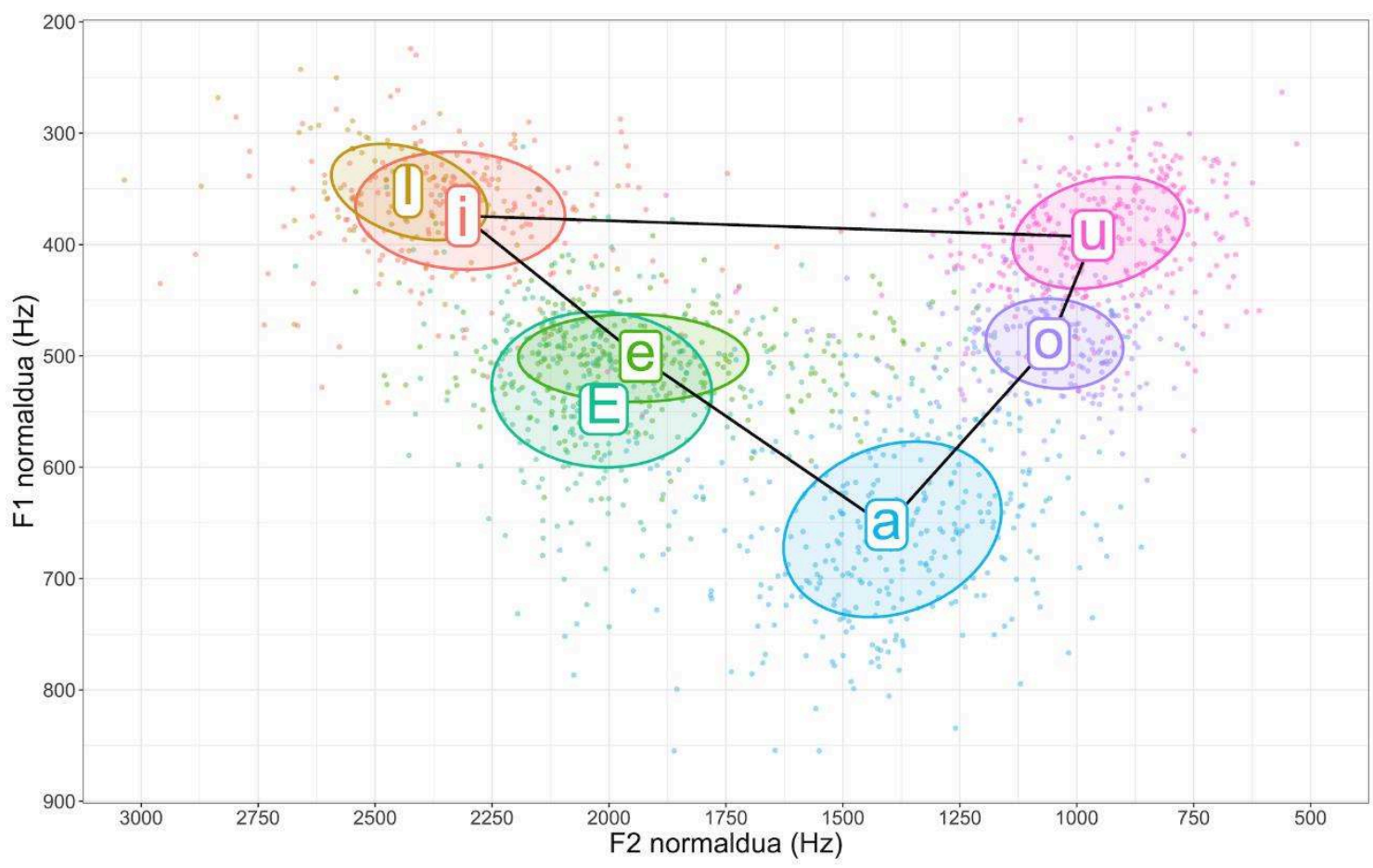

1. Taula: Bokalen lehenengo bi formanteen estatistika laburkina.

\begin{tabular}{|c|c|c|c|c|c|c|c|}
\hline Bokala & $\mathbf{N}$ & $\mathbf{F 1}-\boldsymbol{\mu}$ & $\mathbf{F 2}-\boldsymbol{\mu}$ & $\mathbf{F 1 - S D}$ & $\mathbf{F 2 ~ S D}$ & F1-SE & F2-SE \\
\hline /a/ & 352 & 654.237 & 1410.413 & 77.653 & 241.472 & 8.112 & 25.226 \\
\hline /e/ & 299 & 501.391 & 1930.035 & 44.358 & 266.971 & 5.028 & 30.260 \\
\hline /E/ & 279 & 529.854 & 1960.798 & 74.095 & 304.966 & 8.694 & 35.785 \\
\hline /i/ & 201 & 376.854 & 2298.264 & 58.249 & 273.597 & 8.053 & 37.823 \\
\hline /I/ & 97 & 360.292 & 2403.491 & 53.309 & 295.932 & 10.609 & 58.892 \\
\hline
\end{tabular}


Ander Egurtzegi, Idoia San Martin

\begin{tabular}{|c|c|c|c|c|c|c|c|}
\hline /o/ & 198 & 489.261 & 1069.856 & 42.684 & 188.533 & 5.945 & 26.260 \\
\hline /u/ & 379 & 400.716 & 1023.249 & 66.046 & 348.434 & 6.649 & 35.079 \\
\hline
\end{tabular}

Irudia 2 Bokalen eremu akustikoaren irudikapena parte-hartzaileka

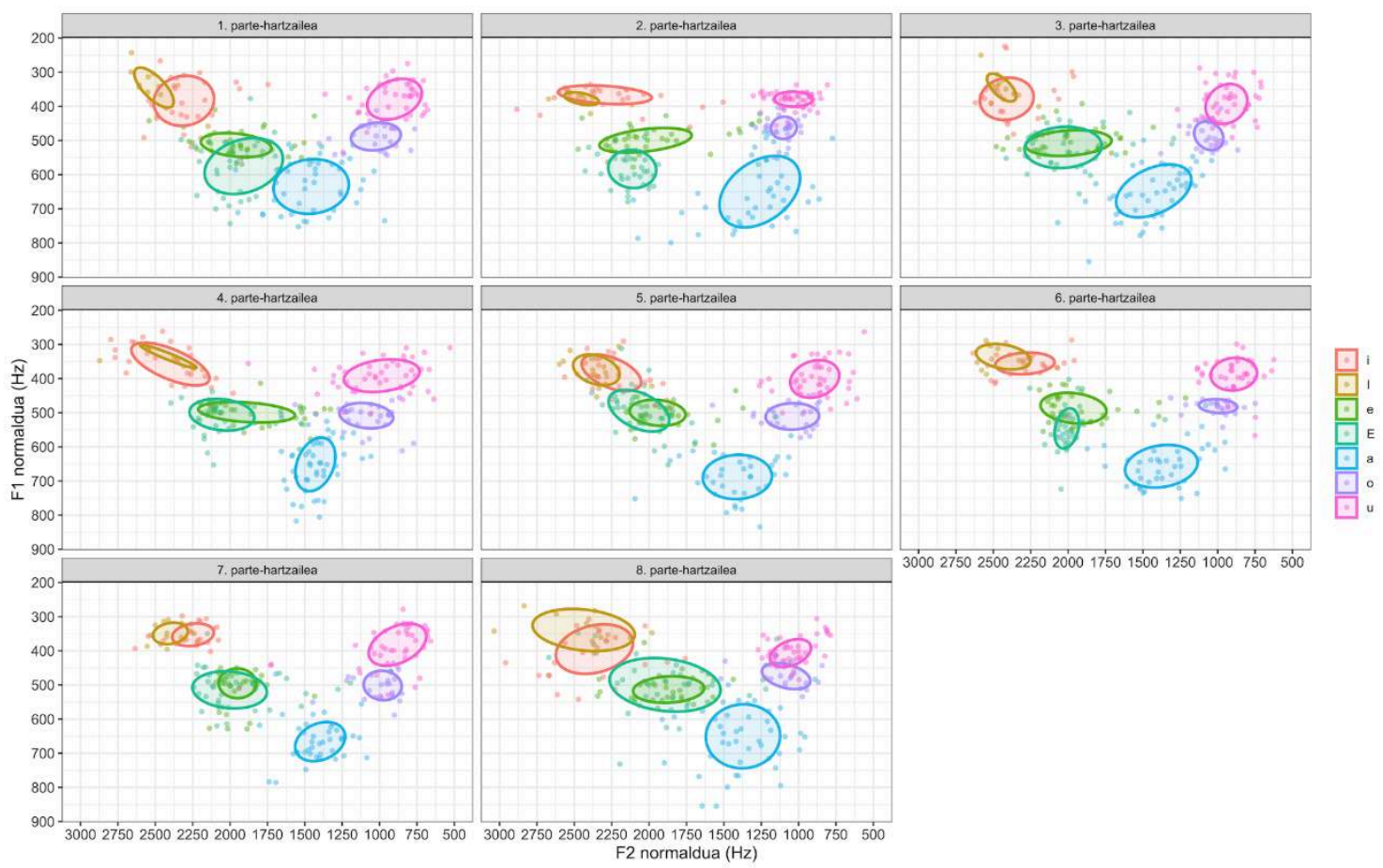

Bai 1. Irudian eta baita 1. Taulan ere, argi geratzen da Zaldibarko euskaran gutxienez 5 bokal ezberdin [a, e, i, o, u] ditugula fonetikoki: goiko bokal bi ([i] eta [u]), erdiko bokal bi ([e] eta [o]), eta beheko bokal bat ([a]). 2. irudiak erakusten du hiztun guztiek bokal horiek argiro bereizten dituztela. [I] eta [i]-ren arteko banaketari dagokionez, ez dirudi gure hiztunek ezberdintasun handirik erakusten dutenik. [E] eta [e]-ren arteko bereizketaren kasua bestelakoa da: 3. eta 8. parte-hartzaileek ezberdintasunik erakusten ez duten bitartean, beste zenbait parte-hartzailek (2.a eta 6.a, esaterako) bi kategoriatzat dituztela iradokitzen du 2. Irudian ikus daitekeen banaketak.

Hurrengo azpiataletan, beraz, [i, e, a, o, u] bost bokalez gain besteren bat ere badagoen egiaztatuko dugu. 


\subsection{Bokal altuera (F1): [i] vs. [I] eta [e] vs. [E]... desberdinak}

ote?

Lehendabiziko begirada batean, ez da ezberdintasunik ikusten [i] eta [I]-ren F1-en artean (376.854 Hz eta $360.292 \mathrm{~Hz}$, hurrenez hurren, ikus 3. Irudia), eta dagoen ezberdintasun urria espero ez dugun noranzkoan agertzen da: [I]-ren F1aren maiztasuna [e] eta [i]-ren maiztasunen artekoa izatea esperoko genukeen /e/ > /i/ igoera bilakabidea oraindik martxan balego, baina gure korpuseko [I]-en batez besteko F1-a maiztasun guztien artean baxuena da (i.e., [I] korpuseko bokal altuena dugu). Kontuan izan behar dugu, ere, [i] eta [I]-ren F1en maiztasunen dispertsioa oso antzerakoa dela $(58.249 \mathrm{~Hz}$ eta $53.309 \mathrm{~Hz}-\mathrm{ko}$ desbiderapen estandarrak dituzte, hurrenez hurren, ikus 4. Irudia). Edonola ere, ezin dugu baztertu gure korpusean agertzen den [I]-ren kopuru baxuak ( $\mathrm{N}=97)$ emaitza baldintzatu dezakeenik.

Argi ikusten da Zaldibarko euskaran beheko bokalaren asimilazioa eragiten duen testuinguru fonologikoan - $a$ determinatzailea [e]-ren eremu akustikotik hurbil ahoskatzen dela. Hala ere, ez dirudi [e] eta [E] berdin-berdinak direnik; haien batez-besteko F1en (501.391 eta $529.854 \mathrm{~Hz}$, hurrenez hurren) arteko ezberdintasuna (28.463 Hz) [i] eta [I]ren artekoa baino handixeagoa da. Gainera, aurreko kasuan ez bezala, honakoan ezberdintasun hau martxan dagoen hots aldaketa batean esperoko genukeen noranzkoan agertzen zaigu. 3. Irudian ikus daitekeen bezala, [E]-ren F1aren maiztasuna [e]-rena eta [a]-renaren artean dago. Honekin batera, [e] eta [E]-ren F1en dispertsioa oso ezberdina da: 4. Irudiak argiro erakusten duenez, [E]-ren F1en desbiderapen estandarrak (74.095 $\mathrm{Hz}$ ) [a]-ren desbiderapen estandarraren antz handiagoa du $(77.653 \mathrm{~Hz})$ [e]-ren SD-arena baino $(44.358 \mathrm{~Hz})$.

3. Irudiko kutxa diagraman (box-plot) eta hurrengoetan, bokal bakoitzaren batezbesteko balioak borobil zuri bezala agertzen dira, medianak lerro beltz horizontal bezala irudikatzen dira eta horren inguruko hozkek errore estandarra erakusten dute. Bi kutxen hozkek ardatz bertikalean ez gainjartzeak medianen arteko ezberdintasuna esanguratsua izan daitekeela iradokitzen du. Kutxek kuartilarteko tartea markatzen dute (datuen erdiko $\% 50$ ), eta "bibote" lerroek kuartilarteko tartea 1.5 aldiz. Muturreko balioak ez dira irudikatu.

Irudia 3 Aurreko bokalen altuera ezberdintasun agregatuak (F1) 
Ander Egurtzegi, Idoia San Martin

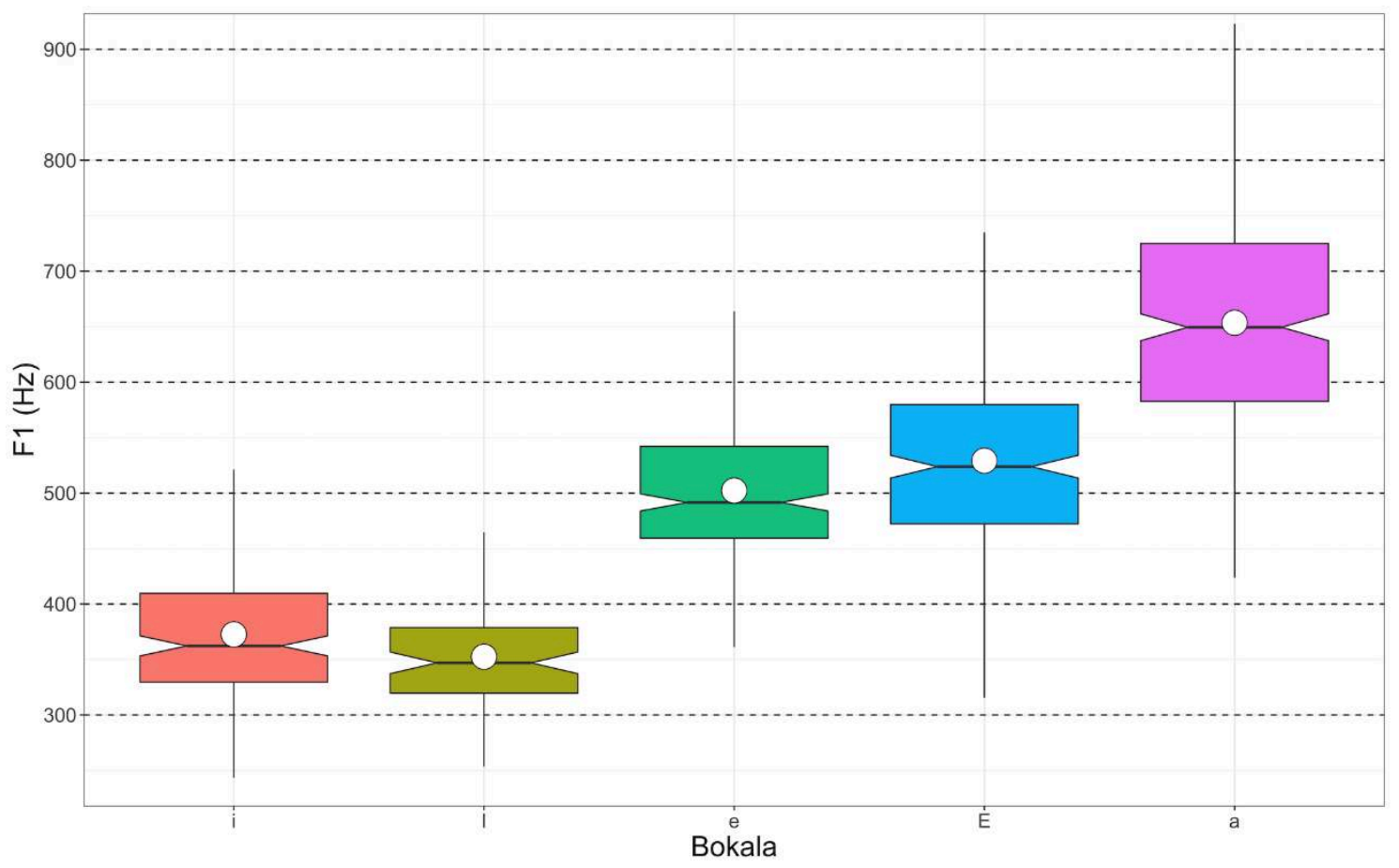

Irudia 4 Aurreko bokalen dentsitate probabilitatea

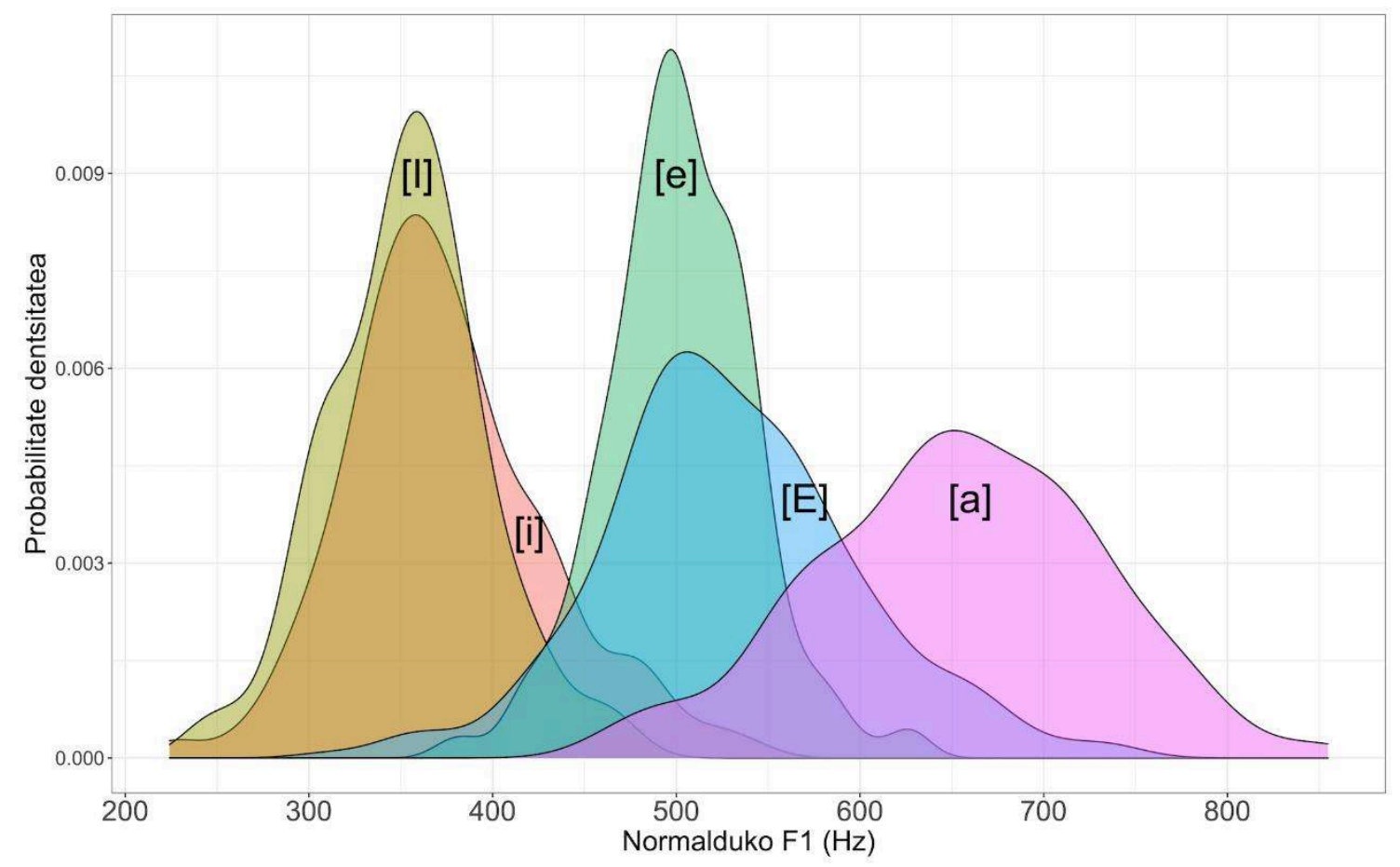

Aurreko bokalen altueren (F1) arteko desberdintasunak aztertzeko eragin bitariko eredu zuzen bat (linear mixed effects model, LME) eraiki dugu lme4 (Bates et al. 2015) $R$ paketea erabiliz. Honakoan, F1 dugu mendeko aldagai edo erantzun gisa, bokala aldagai aske edo eragin finko bezala (fixed effect) eta parte-hartzailea eta hitza ausazko eragin bezala (random effect), ausazko intertzeptu eta maldekin. Tukey post-hoc alderaketak 
eraiki ditugu multcomp (Hothorn et al., 2008) R paketea erabiliz, $\alpha$ maila alderaketa anitzengatik konpentsatuz Benjamini-Hochberg egokitzearen bitartez. Emaitzak 2. Taulan eskaintzen dira, ezberdintasun esanguratsuak 0.05 p-mailan jakinaraziz:

\section{Taula: Bokalen arteko ezberdintasunak F1-ean}

\begin{tabular}{|c|c|c|c|c|}
\hline $\begin{array}{c}\text { Hipotesi } \\
\text { lineala }\end{array}$ & Estimatua & $S E$ & $z$-balioa & $\operatorname{Pr}(>|\mathrm{z}|)$ \\
\hline $\mathrm{I}-\mathrm{i}==0$ & -21.702 & 8.434 & -2.573 & ez esanguratsua \\
\hline $\mathrm{e}-\mathrm{i}==0$ & 120.625 & 6.647 & 18.146 & $<0.001$ \\
\hline $\mathrm{E}-\mathrm{i}==0$ & 153.377 & 6.180 & 24.820 & $<0.001$ \\
\hline $\mathrm{a}-\mathrm{i}==0$ & 280.811 & 6.206 & 45.251 & $<0.001$ \\
\hline $\mathrm{e}-\mathrm{I}==0$ & 142.327 & 8.192 & 17.374 & $<0.001$ \\
\hline $\mathrm{E}-\mathrm{I}==0$ & 175.078 & 7.520 & 23.281 & $<0.001$ \\
\hline $\mathrm{a}-\mathrm{I}==0$ & 302.513 & 7.661 & 39.485 & $<0.001$ \\
\hline $\mathrm{a}-\mathrm{e}==0$ & 32.752 & 5.910 & 5.541 & $<0.001$ \\
\hline
\end{tabular}

\subsection{Bokalen iraupena}

5. Irudian eta 3. Taulan ikus daitekeenez, [E] gure korpuseko bokalik luzeena da, eta baita luzeerari dagokionez dispertsio handiena duena ere. Horren ostean $[\mathrm{I}]$ dator, gero $[\mathrm{u}],[\mathrm{e}]$, [a], [o] eta, azkenik, [i]. [E]-k oso dispertsio handia erakusten du, bokal honen 
distribuzioaren erdiko \%50-k 100 ms. baino gehiago hartzen dituela, hurrengo bokalen bikoitzetik gertu.

Irudia 5 Bokalen iraupen agregatua

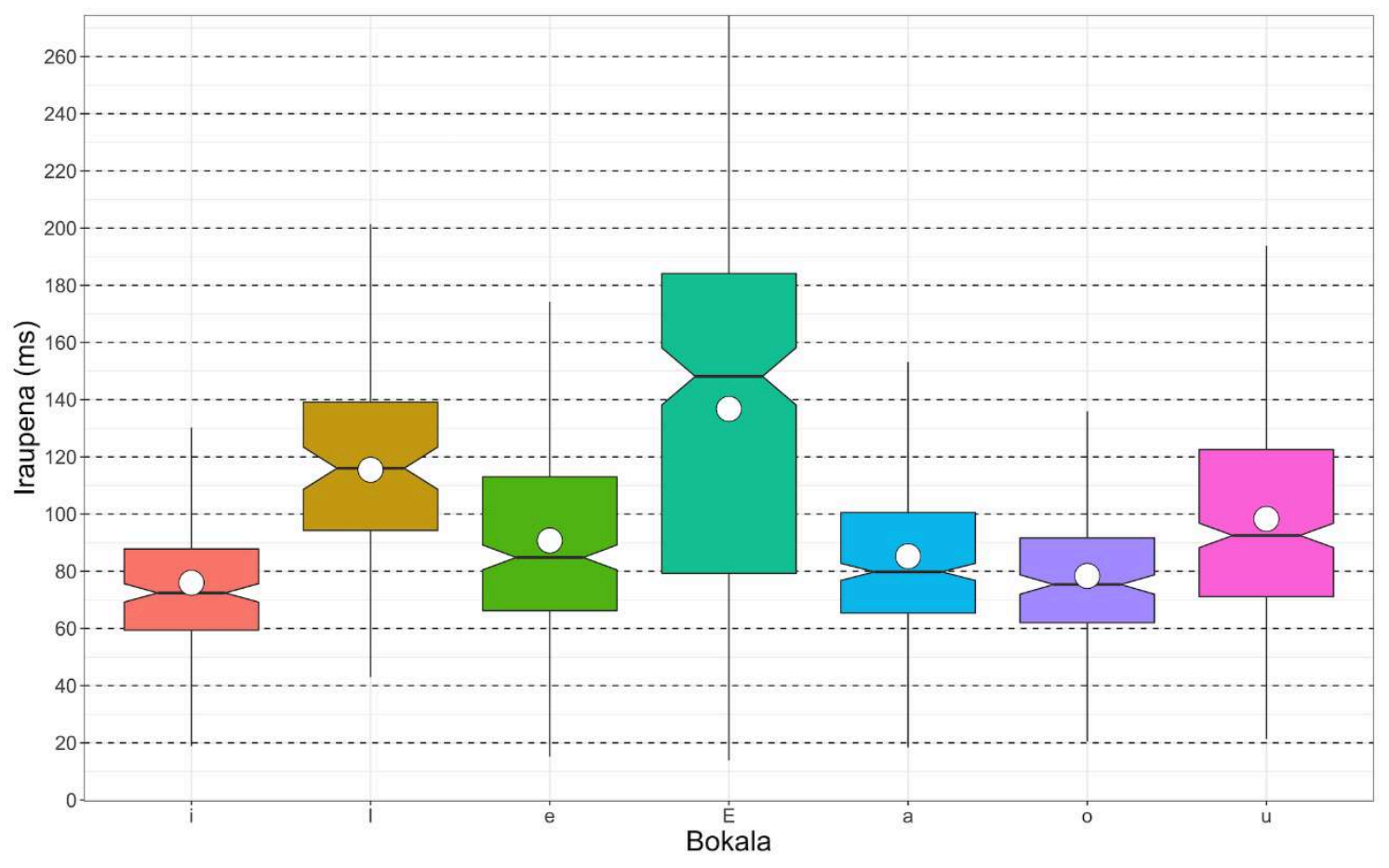

3. Taula: Bokalen iraupenaren (ms.) estatistika laburkina.

\begin{tabular}{|c|c|c|c|c|}
\hline Bokala & $\mathbf{N}$ & Iraup.- $\boldsymbol{\mu}$ & Iraup.-SD & Iraup.-SE \\
\hline /a/ & 352 & 87.773 & 37.381 & 3.905 \\
\hline /e/ & 299 & 94.027 & 43.114 & 4.887 \\
\hline /E/ & 279 & 136.041 & 60.725 & 7.125 \\
\hline /i/ & 201 & 77.812 & 33.241 & 4.595 \\
\hline /I/ & 97 & 114.71 & 34.918 & 6.949 \\
\hline /o/ & 198 & 79.205 & 27.589 & 3.843 \\
\hline
\end{tabular}


Ander Egurtzegi, Idoia San Martin

\begin{tabular}{|l|l|l|l|l|}
\hline$/ \mathrm{u} /$ & 379 & 98.81 & 39.513 & 3.978 \\
\hline
\end{tabular}

Aipatu behar da [E]-ren dispertsioaren balio deigarriak ez direla token kopuruaren ondorio: gure korpusean dauden bokalen artean erdi-erdian dago [E] (hiru bokalek token gehiago dituzte, beste hiruk gutxiago), eta beste bokalek ez dute horrelako distribuziorik erakusten. 6. Irudian iraupen ezberdintasunak hiztunen arabera alderatu daitezke.

\section{Irudia 6 Bokalen iraupena parte-hartzaileka}

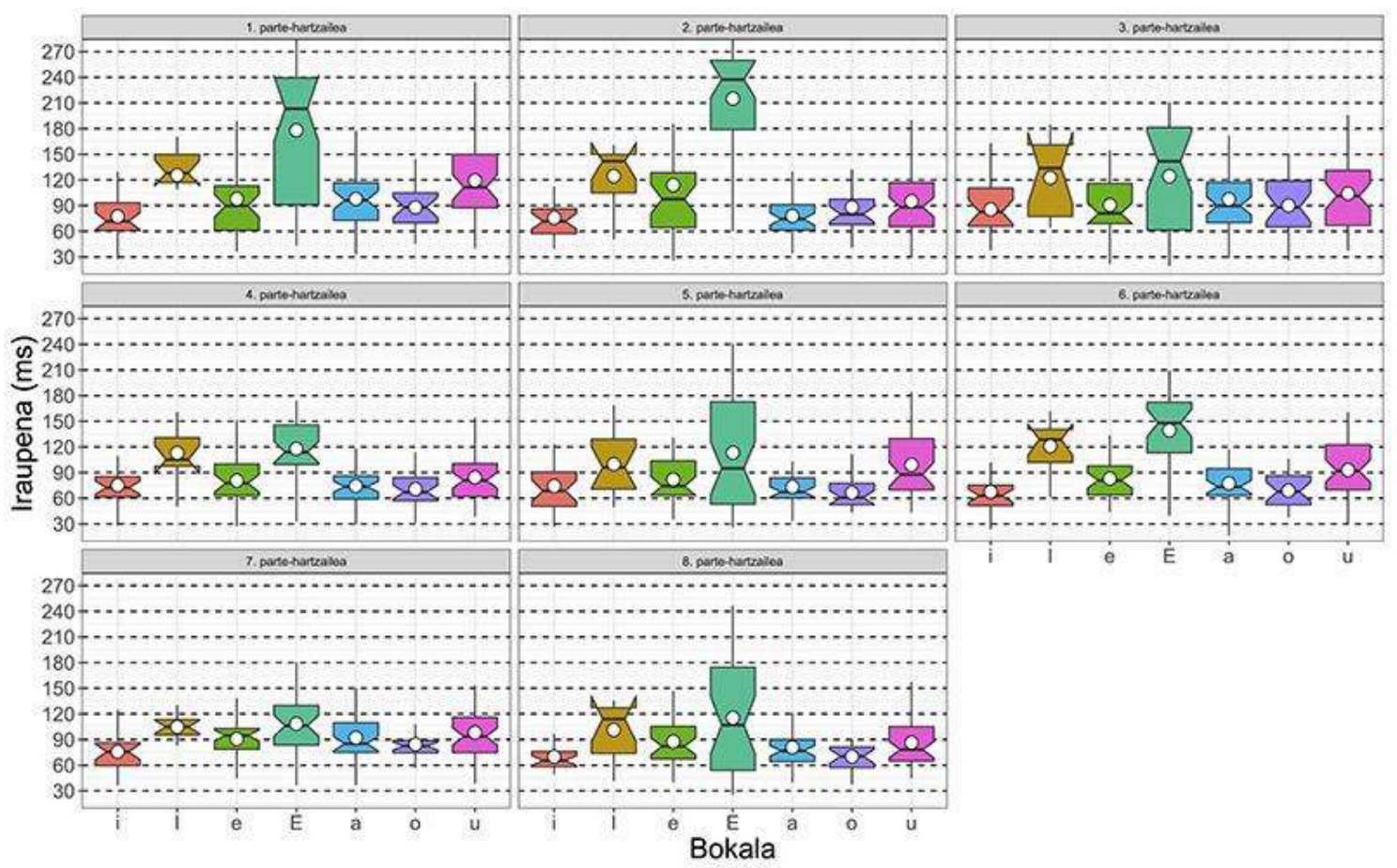

6. Irudiak borobil zurien bidez erakusten duen bezala, gure korpuserako grabatu ditugun hiztun guztien kasuan [E] da batez beste luzeen ebakitzen den bokala. Honekin batera, 1., 3., 5. eta 8. parte-hartzaileek dispertsio handia erakusten dute haien [E]-ren iraupenean. Aipagarria da zenbaki bakoitidun parte-hartzaileak emakumeak direla, eta grabatu ditugun lau emakumetik hiruk erakusten dutela aipatutako patroi hau (eta gizon bakarrak).

Gure emaitzetan ikus daitezkeen iraupen luzea eta dispertsio maila handia ez dira ikergai dugun hots aldaketaren ondorio. Zentralizazioa edota bokal igoera eragiten duen aldaketa batean kontrakoa esperoko genuke, bokalaren iraupena laburtzea, alegia. Patroi hau azaltzen duen arrazoirik egiantzekoena gure korpusaren diseinuan aurkitzen dugu. Izan ere, kasu gehienetan, [E] bokala esaldiaren azkenengo segmentua da gure korpuseko 
esaldi eta hitzetan. ${ }^{8}$ Distribuzio honen ondorioz, [E] bokala hiztun guztiok konturatu gabe egiten dugun esaldi-amaierako luzatzearen (ikusi Edwards et al. 1991) menpe dagoen ia segmentu bakarra da. Ondorioz, hiztun guztien kasuan da bokalik luzeena, baina datu hau ezin dugu kontuan hartu Zaldibarko hizkeraren bokalen luzeraren deskribapenerako, esaldi-mailako efektu baten ondorioa baino ez delako. Hurrengo ikerketetan esaldiak moldatuko ditugu arazo hau ekiditeko.

\subsection{Beheko bokalaren igoera belaunaldiei begira}

Behin zehaztuta igoera testuinguruetan agertzen den /a/ $\sim[\mathrm{E}]$ eta beste edozein testuinguruko /e/ [e]-ren arteko ezberdintasuna estatistikoki esanguratsua dela (ikus 3.2), hurrengo galdera segmentu honen ahoskera /e/-ren ebakerari hurbiltzera eramango duen hots aldaketa bat martxan den edo egun dagoen kokapenean egonkortu den jakitea da. Helburu horrekin, determinatzailearen ahoskeran dauden gure korpuseko bi belaunaldien arteko ezberdintasunak konparatu ditugu.

7. Irudian gazte eta helduen arteko [E]-en F1 ezberdintasunei erreparatzen badiegu, gazteen bokalaren batezbesteko F1 helduena baino baxuagoa dela ikus dezakegu. Honakoa hots aldaketa martxan egongo balitz espero ez genukeen emaitza da. Hala ere, ia bokal guztien F1-ak altuagoak direnez gazteen kasuan, bi belaunaldien arteko [E]-en arteko ezberdintasunak neurtzeko eredu lineal bat eraiki dugu.

Irudia 7 F1 (Hz) desberdintasunak adin-taldeen arabera

8 Izaro Bedialaunetari (k.p.) eskertzen diogu gabezia honen identifikazioa. 


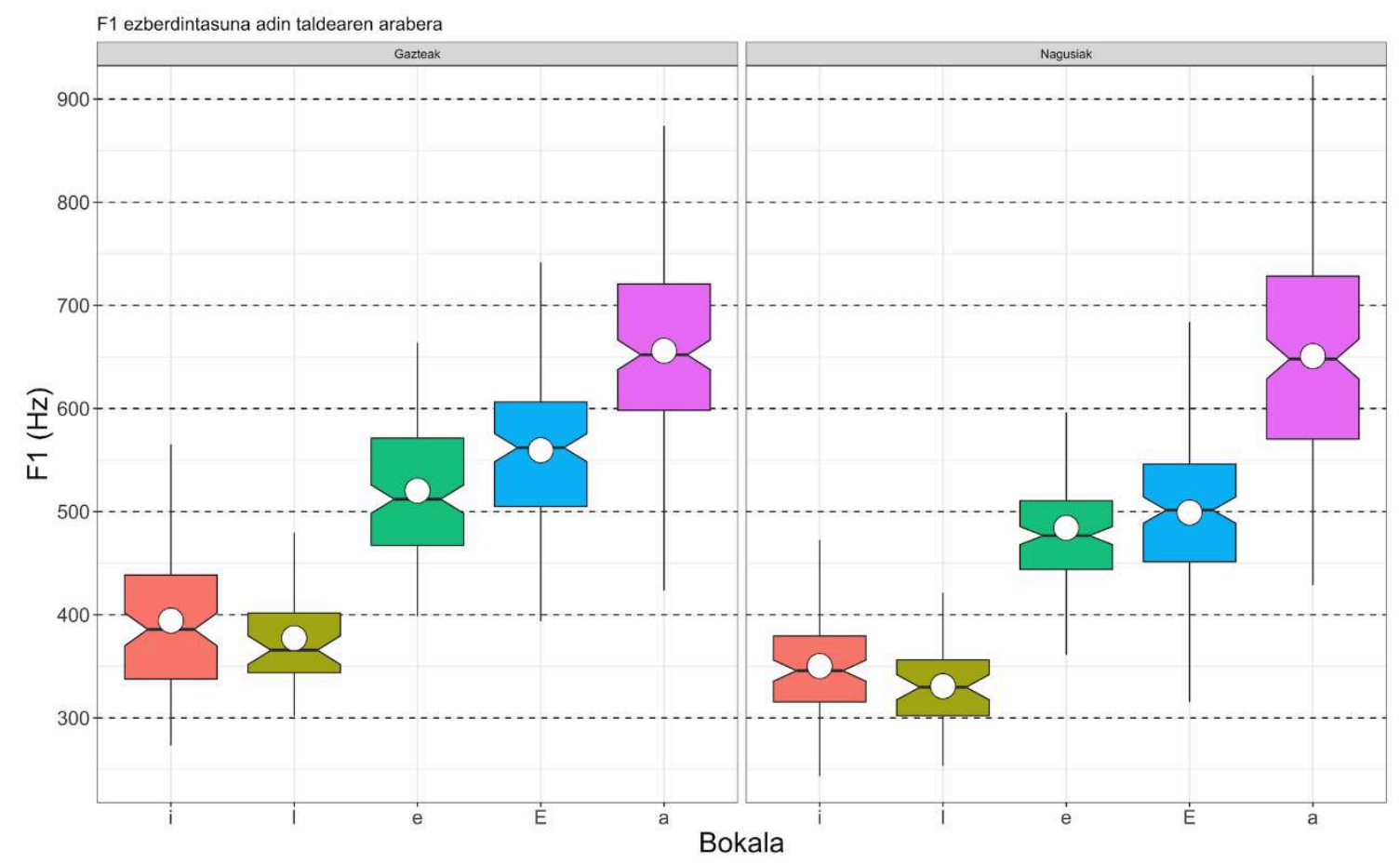

Honetarako, bi belaunaldien [E] bokalen F1-ak konparatu ordez, hauen F1 eta F2-ren arteko diagonalak alderatu ditugu. Bokalen diagonala $\mathrm{F} 2-\beta * \mathrm{~F} 1$ bezala kalkulatu dugu, non $\beta=2$ den balio gordinen kasuan (Labov et al 2013: 40) eta $\beta=1$ den z-balioak erabiltzean (Fruehwald 2013: 81). Eredu honetan normalizatu gabeko balioak erabili ditugunez, aurreko diagonala F2 - 2* F1 bezala kalkulatu dugu. Honenbestez, diagonala hiztunaren belaunaldiaren funtzio bezala duen LME eredu bat osatu dugu, partehartzailea eta hitza ausazko intertzeptu eta malda bezala jarrita. Alderaketak ez du desberdintasun esanguratsurik erakutsi adinari dagokionez. ${ }^{9}$

\subsection{Igurzkari aurresabaikariaren ahotsa}

Gaminderen arabera (2003: 428), Zaldibarko hiztun helduek sabaiaurreko igurzkaria ahostun ebakitzen dute, baina hiztun gazteek honezkero segmentu honen ahoskabetzea erakusten dute. Gure korpusari begira, baieztapen hau betetzen da.

4. Taulak eta 8. eta 9. Irudiek ematen dute [3] [ ] -ren ahoskeraren berri. Irudiak begiratzerakoan, gogoan izan AC koefizienteek ahotsaren berri ematen digutela (hau da, 1 erabateko korrelazioa —ahostuna—, 0 inongo korrelaziorik ez —ahoskabea). Erdiko

9 Nahiz eta gure ikerketa galderaren parte ez izan, hiztunaren generoa aldagai aske bezala duen honen antzeko eredu bat eraiki dugu ere. Kasu honetan ere, "gizon" eta "emakume" mailen arteko ezberdintasuna ez da esanguratsua gure ereduaren arabera. 
balioa (0.5) baino altuagoak diren balioak soinu ahostunei dagozkie eta 0.5 baino txikiagoak direnak hots ahoskabeei lotzen zaizkie.

Nahiz eta datu gutxi ditugun (gure ikerketaren hasierako helburua ez izatearen ondorioz), gure bi adin taldeetan ikus daiteke aldaera ahoskabea erabiltzearen aldeko joera, zeina gazteen kasuan erabatekoa den: ez da ahostunaren adibiderik agertzen adin-talde horretan, 4. Taulan eta 8. eta 9. Irudietan ikus daitekeen bezala. Modu berean, eta nahiz eta bi adin taldeetan ahoskabetzerako joera egon, gazte eta nagusien arteko ezberdintasuna nabaria dela esan daiteke, azken hauek askoz gehiagotan erabili baitute igurzkari ahostuna ( 8 guztira). Bi parte-hartzailerengandik baino ez dira jaso ebakera ahostunak: 5. parte-hartzailea (emakumea), eta 8. parte-hartzailea (gizona). 5. partehartzaileak kasu guztietan ahostuna ebaki duen bitartean $(6 / 6,100 \%)$, 8. parte-hartzaileak birritan baino ez du igurzkari ahostuna ahoskatu (2/5, \%40).

\section{Taula: [3] []-ren ahoskera parte-hartzaileka, adin taldeka eta guztira.}

\begin{tabular}{|c|c|c|c|}
\hline Parte-hartzailea & [3] & {$[S]$} & Guztira \\
\hline 1. & 0 & 6 & 6 \\
\hline 2. & 0 & 5 & 5 \\
\hline 3. & 0 & 4 & 4 \\
\hline 4. & 0 & 6 & 6 \\
\hline Gazteak guztira: & 0 & 21 & 21 \\
\hline 5. & 6 & 0 & 6 \\
\hline 6. & 0 & 4 & 4 \\
\hline 7. & 0 & 6 & 6 \\
\hline 8. & 2 & 3 & 5 \\
\hline
\end{tabular}


Ander Egurtzegi, Idoia San Martin

\begin{tabular}{|c|c|c|c|}
\hline Nagusiak guztira: & 8 & 13 & 21 \\
\hline Guztira & 8 & 34 & 42 \\
\hline
\end{tabular}

Irudia 8 [3] []-ren ahoskera adin taldearen arabera

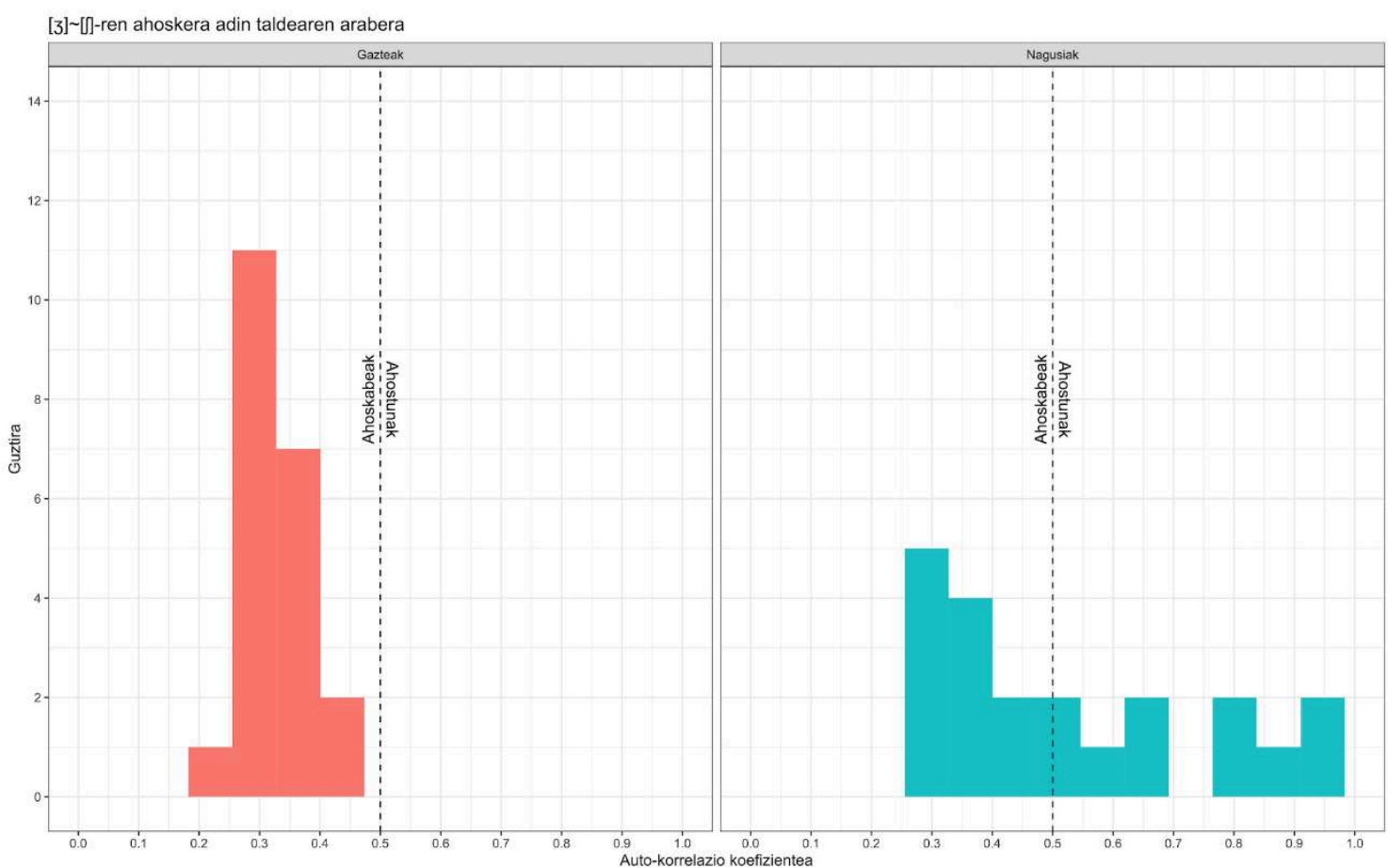

Irudia 9 Igurzkari aurresabaikariaren ahotsa adin taldearen arabera 


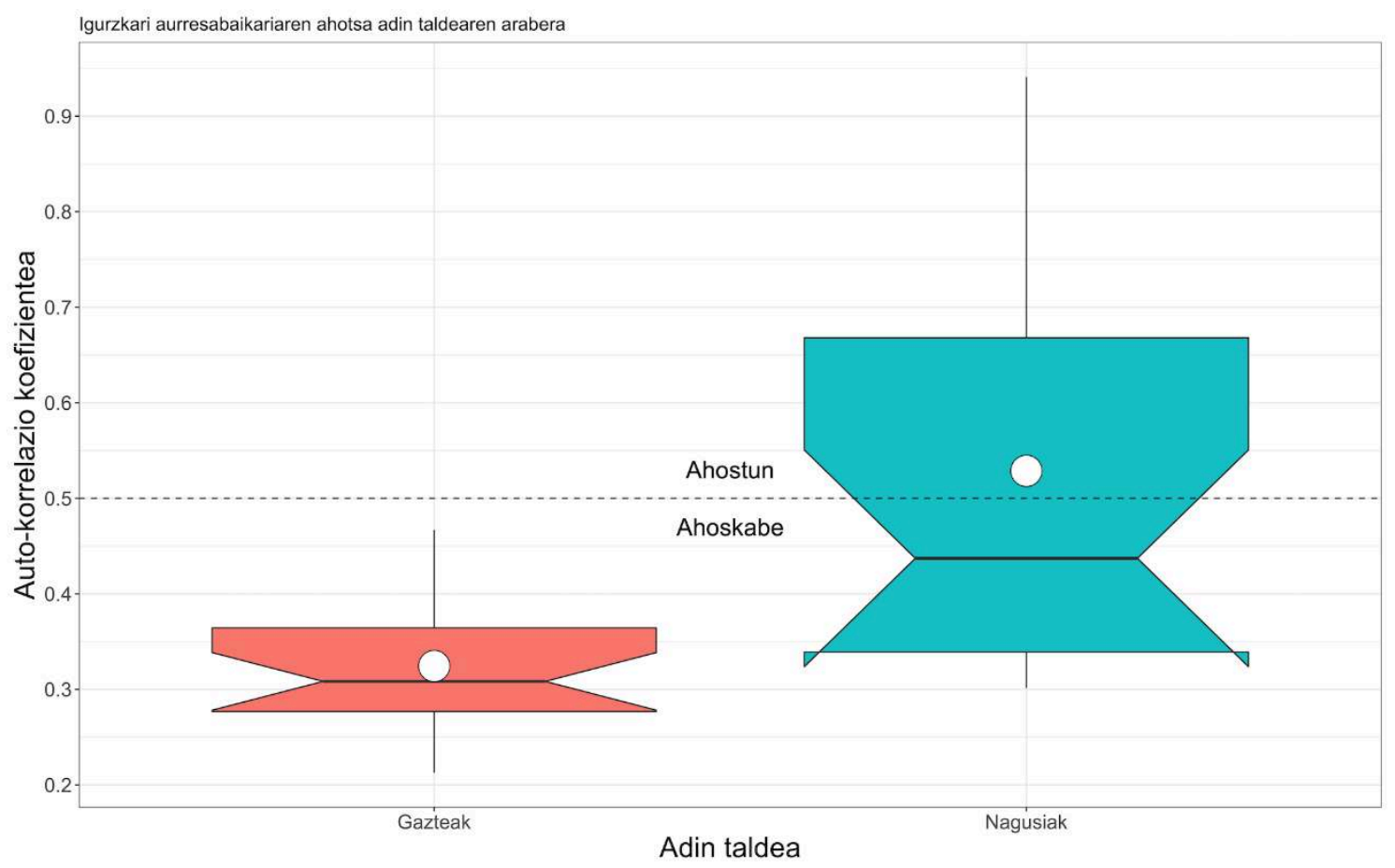

8. eta 9. Irudietan ikus daitekeenez, helduek ahostun/ahoskabe muga zeharkatzen duen bariazioa erakusten dute, baina, hauek ez bezala, gazteek ez dute bariaziorik erakusten. Nahiz eta 9. Irudian helduen batezbestekoa 0.5 marraren gainean dagoen, kasu honetan esanguratsuagoa den mediana 0.45 baino beherago agertzen zaigu, ahoskabe eta ahostun kategoriak banatzen dituen erdi-puntutik behera. Emaitza hauek gure ikerketako helduen belaunaldian ahoskabetzea joera nagusia zelako ebidentzia mugatutzat har daitezke.

\section{EZTABAIDA}

Bibliografian oinarrituta, /a/ [E] eta /e/ [e]-ren arteko ezberdintasunik ez egotea espero genuen, honakoa bakarrik Azpeitia eta Azkoitiako euskaran deskribaturik izan den heinean, beste hizkeretan bi bokalen arteko fusioa espero genuela (Hualde 2003: 46). Hala ere, gure datuek, bai kutxa diagramak eta baita modelo estatistikoak ere, bi segmentu hauen arteko ezberdintasun esanguratsua iradokitzen dute F1-ri dagokionean. [E] bezala markatu dugun bokal hau, Azpeitia eta Azkoitiako hizkeren kasuan bezala, /a/ eta /e/-ren ebakeren artean kokatzen dela ikusi dugu. Gauzak horrela, eta hots hau Zaldibarko hizkerako gainontzeko [e]-etatik oso ezberdina ez dela ikusita, [ẹ] bezala deskribatu daitekeela proposatzen dugu. Aipatu behar da [ẹ] ez dela segmentu beregaina Zaldibarko hizkeran, /a/-ren alofonoa baizik: aurreko silaban /i/ edo /u/ bat dagoenean ebakitako /a/ren aldagaia dugu [ẹ].

Durangaldean beheko bokalaren asimilazioa XIX-XX. mendeetan garatutako bilakabide bat izan daitekeenez, bokal honen kokapena konparatu dugu ikertutako bi belaunaldien artean $(\mu=23.5$ eta $\mu=57.75)$, igoera prozesua honezkero osatua dagoen zehazteko. Gure 
emaitzen arabera, ez dirudi ikertutako bokal igotzea aurrera doanik Zaldibarren: gure datuen arabera, ezberdintasun gutxi dago adin-tarte baten eta beste adin-tartearen hiztunen artean bokal honen ebakerari dagokionean. Are gehiago, dagoen ezberdintasun urria espero ez genukeen noranzkoan agertzen zaigu, gazteen [E]-ak helduenak baino pixka bat baxuagoak baitira, batez beste. Gazteen bokal guztiak baxuagoak direnez, honakoa ezin da hots aldaketaren atzera eramate bat bezala ikusi. Edonola ere, emaitza hau asimilazioaren ondoriozko igoera, oraingoz, [E] eta /e/-ren arteko fusioan amaituko ez denaren erakusle bezala interpretatzen dugu.

Bestalde, morfema mugan sortutako bokal topaketen ondoriozko bokal igoerei dagokienez, /e/ + /a/ > /ie/ eta /a/ + /a/ > /ie/ bezalakoetan aurki daitekeen [I] hori neurtu dugu eta hizkeran agertzen diren beste /i/-ekin alderatu, eta desberdintasun esanguratsurik ez dagoela ondorioztatu dugu. Bilakabide hau beheko bokalaren asimilazioa baino lehenago garatu zenez Zaldibarren, emaitza hau bilakabideen kronologiaren ildo beretik doala pentsa daiteke.

Bokal ezberdinen iraupena ere neurtu dugu, baina, tamalez, neurketek eman diguten informazioa ez da lagungarria izan. Asimilatutako bokal bat beste bokalak baino laburragoa izan zitekeela pentsagarria da, baina gure emaitzetan kontrakoa ikusi dugu: bokal guztien artean luzeena da [E], eta bere iraupenean bariazio handia erakusten du. Honakoa gure korpusaren arazotzat dugu, [E] gehienak esaldi amaieran egotearen ondorioz esaldi-amaierako luzatzearen menpe baitaude, gainontzeko bokalak kokapen honetan gutxi agertzen diren bitartean.

Azkenik, [3] [J]-ren ahoskera analizatu dugu. Zortzi parte-hartzaileetatik helduen taldeko bi hiztunek bakarrik sortu dituzte ahoskera ahostunak: batek sistematikoki, eta besteak \%40an. Gazteen artean, ordea, inork ez du igurzkari aurresabaikari ahostunik ahoskatu. Ondorioz, gure datu mugatuen arabera, [3]-ren ahoskabetzea Zaldibarren belaunaldi honetan amaitu dela dirudi, aurreko belaunaldian dagoeneko oso aurreratua, baina oraindik bukatu gabe zegoelarik.

\section{ONDORIOAK}

Ikerlan honek Zaldibarko euskararen hainbat ezaugarri akustiko landu ditu, denak morfema mugetan garatu diren bilakabide (morfo-)fonologikoei loturik. Artikulu honen interes nagusia beheko bokalaren asimilazioaren ondoriozko [E] determinatzaile mugatuaren izaera akustikoa ikertzea izan da, hizkerako beste /e/-ekin alderatuz. Azterketa honen emaitzen arabera, [E] fonetikoki ezberdina da, /a/ eta /e/-ren ebakeren tarteko bokal bat, alegia, agian [e] bezala deskribatu genezakeena. Honetaz gain, /a/-ren alofono hau /e/-rekin batzeko bidean ez dagoela ikusi dugu, oraingoz behintzat. 
Honekin batera, beste zenbait emaitza aurkeztu dira: morfema mugako bokal igoeraren ondoriozko [I] bokala hizkerako beste /i/-en modu berean ahoskatzen dela ondorioztatu dugu, eta [3]-ren ahoskabetzea azken belaunaldi honetan osatu dela egiaztatu dugu. Bokalen iraupena ere neurtu dugu, baina neurketa hauetatik ez dugu ondorio zehatzik atera ahal izan. Azkenik, ikerketa honetarako prestatutako audio bilduma baliatuz, Zaldibarko bokalen eremu akustikoa deskribatu dugu.

Ikerketa honetako emaitzek [E]-ren eta [I]-ren haien inguruko bokalekiko erlazio ezberdinak erakutsi dituzte. Lehena, [e]], /a/-ren alofono bezala analizatu behar dugun eta orain arte hizkera horretan deskribatu izan ez den aldagai fonetiko bat dela ikasi dugu. Bestalde, bigarrena /i/-ren beste gauzatzeen antzekoa den [i] dela zehaztu dugu. Lan honek euskararen bokalen bilakabide fonologiko askoren inguruko xehetasun fonetikoak ezezagun ditugula azpimarratu du, azterketa fonetikoen bidez bilakabide fonologikoak hobeto ulertzera heldu gaitezkeela erakutsiz.

\section{ERREFERENTZIAK}

Audacity Team. 2019. Audacity(R): Free Audio Editor and Recorder. Software programa. https://audacityteam.org/.

Aurrekoetxea, G., Gaminde, I., Ormaetxea, J.L. \& Videgain, X. 2019. Euskalkien sailkapen berria. Bilbo: UPV/EHU.

Azaola, L. 2019. Durangoko euskararen bilakaera XVI-XXI. mendeetan zehar. Zenbait ezaugarri bokalikoren azterketa eta lekukotzea. Hitzaldia Euskal Filologiaren adarrak 2 jardunaldian (2019/10/30).

Bailey, G., Wikle, T., Tillery, J. \& Sand, L. 1991. The apparent time construct. Language Variation and Change 3.3, 241-264. https://doi.org/10.1017/S0954394500000569.

Blevins, J., Egurtzegi, A. \& Ullrich, J. 2020. Final obstruent voicing in Lakota: Phonetic evidence and phonological implications. Language 96.2, 294-337. https://doi.org/10.1353/lan.2020.0022.

Boersma, P. \& Weenink, D. 2019. Praat: doing phonetics by computer. Software programa. http://www.praat.org/.

Bonaparte, L.L. 1863. Carte des sept provinces Basques. Londres.

Cukor-Avila, P. \& Bailey, G. 2013. Real time and apparent time. J.K. Chambers eta N. Schilling (arg.), The handbook of language variation and change (2. arg.). Malden, MA: Wiley-Blackwell, 237-262. 
de Castro-Arrazola, V., Cavirani, E., Linke, K. \& Torres-Tamarit, F. 2015. A typological study of vowel interactions in Basque. Isogloss 1, 147-177.

de Rijk, R.P.G. 1970. Vowel interaction in Bizcayan Basque. Fontes Linguae Vasconum 2, 149-167.

Edwards, J., Beckman, M.E. \& Fletcher, J. 1991. The articulatory kinematics of final lengthening. The Journal of the Acoustical Society of America 89, 369-382. http://doi.org/10.1121/1.400674.

Egurtzegi, A. \& Carignan, C. 2020. An acoustic description of Mixean Basque. The Journal of the Acoustical Society of America 147.4, 2791-2802. http://doi.org/10.1121/10.0000996.

Fruehwald, J. 2013. The phonological influence on phonetic change. Doktorego tesia, Philadelphia: University of Pennsylvania.

Gaminde, I. 1988. Ahozko bizkaieraz. Bilbo: Bizkaiko AEK.

Gaminde, I. 1993. Bokalen asimilaziorako erregela fonologikoak Bizkaiko euskaran. Enseiukarrean 9, 51-61.

Gaminde, I. 2002. Bizkaiko euskararen ezaugarri fonologiko batzuen inguruan. Euskalingua 1, 4-14.

Gaminde, I. 2003. Zaldibar berbarik berba. Zaldibar: Zaldibarko Udala.

Harrington, J. 2010. Phonetic analysis of speech corpora. Chicester: Wiley-Blackwell.

Hualde, J.I. 1991. Basque phonology. London \& New York: Routledge.

Hualde, J.I. 1999. Vowel interaction and related phenomena in Basque and the nature of morpho-phonological knowledge. Cognitive Linguistics 10, 33-56. http://dx.doi.org/10.1515/cogl.1999.002.

Hualde, J.I. 2003. "Segmental phonology”. In Hualde, J.I. \& Ortiz de Urbina, J. (arg.), A grammar of Basque. Berlin: Mouton de Gruyter, 15-65.

Hualde, J.I. \& Gaminde, I. 1998. Vowel interaction in Basque: A nearly exhaustive catalogue. Studies in the Linguistic Sciences 28, 41-77.

Kenstowicz, M. 1994. Phonology in Generative Grammar. Cambridge, MA \& Oxford: Blackwell. 
Kisler, T., Reichel, U.D. \& Schiel, F. 2017. Multilingual processing of speech via web services. Computer, Speech \& Language 45, 326-347. WebApp: https://clarin.phonetik.uni-muenchen.de/BASWebServices/interface.

Labov, W. 1994. Principles of linguistic change. Vol. 1: Internal factors. Oxford: Blackwell.

Labov, W., Rosenfelder, I. \& Fruehwald, J. 2013. One hundred years of sound change in Philadelphia: Linear incrementation, reversal, and reanalysis. Language 89, 30-65. https://doi.org/10.1353/lan.2013.0015.

Larramendi, M. 1745. Diccionario trilingue del castellano, vascuence y latín. Donostia: B. Riesgo y Montero.

Leizarraga, J. 1571. Iesus Krist Gure Iaunaren Testamentu Berria. Arroxela.

Manterola, J. 2015. Euskararen morfologia historikorako: artikuluak eta erakusleak. Doktorego tesia, Gasteiz: UPV/EHU.

Oihenart, A. 1656. Notitia utriusque Vasconiae tum Ibericae tum Aquitanicae (2. arg. osatua) [J. Gorosteratzu itzultzaile]. Revista Internacional de Estudios Vascos 17-19. Bilbo: La Gran Enciclopedia Vasca, 1971-1972 [Berrargitaratua, 1992, Gasteiz: Eusko Legebiltzarra].

Oñederra, L. 2005. Fonologiaren mugak: alabea eta birjinak elexan. In P. Etxeberria \& H. Knörr (arg.), Nerekin yaio nun: Txillardegiri omenaldia. Bilbo: Euskaltzaindia, 379397.

R Core Team. 2019. R: A Language and environment for statistical computing. Software programa. http://www.R-project.org.

Trask, L. 2015. Historical linguistics [R. McColl Millar (arg.)]. Londres \& New York: Routledge.

Weinreich, U., Labov, W. \& Herzog, M. 1968. Empirical foundations for a theory of language change. In W. Lehmann, \& Y. Malkiel (arg.), Directions for historical linguistics. Austin: University of Texas Press, 97-195.

Winkelmann, R. 2017. The EMU-SDMS. Doktorego tesia, Munich: LMU. Software programa. https://cran.r-project.org/package=emuR.

Yrizar, P. de. 1991. Morfología del verbo auxiliar guipuzcoano: Estudio dialectológico. Bilbo: Euskaltzaindia. 
Ander Egurtzegi, Idoia San Martin

Zuazo, K. 1998. Euskalkiak, gaur. Fontes Linguae Vasconum 78, 191-234.

Zuazo, K. 2003. Euskalkiak. Herriaren lekukoak. Donostia: Elkar

Zuazo, K. 2008. Euskalkiak, euskararen dialektoak. Donostia: Elkar.

Zuazo, K. 2014. Euskalkiak. Donostia: Elkar.

Zuazo, K. 2017. Mendebaleko euskara. Donostia: Elkar.

Zuazo, K. 2019. Standard Basque and its dialects. Londres: Routledge.

Zuloaga, E. 2015. Diego Lorenzo Urkizuren 1740ko zortzikoak. ASJU 49, 179-201.

Zuloaga, E. 2017. Beheko bokalaren asimilazioaren historiarako: Mendebaleko datuak. Fontes Linguae Vasconum 123, 167-199.

Zuloaga, E. 2019. Mendebaleko euskararen azterketa dialektologiko-diakronikorantz. Doktorego tesia, Gasteiz: UPV/EHU. 